\section{Energy Performance, Indoor Air Quality and Comfort in New Nearly Zero Energy Day-care Centres in Northern Climatic Conditions}

\section{Kalle Kuusk}

Tallinn University of Technology, Estonia

\section{Ahmed Kaiser}

Aalto University, Finland

\section{Nicola Lolli}

SINTEF, Norway

\section{Jan Johansson}

Växjö Kommun, Sweden

\section{Tero Hasu}

Kouvola Innovation Ltd., Finland

\section{Anne Gunnarshaug Lien}

SINTEF, Norway

\section{Endrik Arumägi, Kristo Kalbe, Jaanus Hallik}

Tallinn University of Technology, Estonia

\section{Jarek Kurnitski}

Aalto University, Finland

\section{Targo Kalamees*}

Tallinn University of Technology, Estonia

*Corresponding author: targo.kalamees@taltech.ee

$\Gamma$ crossef http://dx.doi.org/10.5755/j01.sace.24.1.22180

The European energy policy pushes the member states to transform building stock into nearly ZeroEnergy Buildings (nZEB). This paper is focused on data collected from existing nZEB day-care centres, in order to be able to assess possible differences between predicted and actual energy and indoor environmental performance. Building structures, service systems and the indoor climate and energy performance of five day-care centres were investigated in Estonia, Finland and Norway.

Indoor climate condition measurements showed that in general, the thermal environment and indoor air quality corresponded to the highest indoor climate categories I and II (EN 15251). Building heating and ventilation systems in studied buildings are working without major problems. Good indoor climate conditions
JSACE $1 / 24$

Energy Performance, Indoor Air Quality And Comfort in New Nearly Zero Energy Day-Care Centres in Northern Climatic Conditions

Received 2018/12/11

Accepted after revision 2019/01/14

\section{ktu 1922}

Journal of Sustainable Architecture and Civil Engineering vol. 1 / No. 24 / 2019 pp. 7-16 DOI 10.5755/j01.sace.24.1.22180 
were also reflected in the occupant satisfaction questionnaires. For most of the studied buildings, over $80 \%$ of the people marked all indoor environment condition parameters (thermal comfort, indoor air quality, acoustics, odour and illuminance) acceptable. The thermal environment in the cooling season was reported problematic because it was lower than the minimum temperature for indoor climate category II.

Energy consumption analysis showed that measured real energy use was higher, or even significantly higher, than the energy use calculated during the design phase. Potential causes of the higher actual energy consumption are caused by differences of measured and designed solutions, methodology of the energy calculations, and the differences in user behaviour.

Lessons learnt from previously constructed day-care centres can be utilised in the planning and design of new nZEBs.

Keywords: indoor thermal conditions, indoor air quality, occupant satisfaction, energy consumption, nZEB, day-care centres.

By the end of 2020 (2018) for buildings occupied and owned by public authorities), all new buildings should comply with the Energy Performance of Buildings Directive (EPBD, 2010) obligations. Many member states (MS) have already shifted minimum requirements to the cost optimal level. Kurnitski et al., (2018)as the latter was needed for comparing with the national NZEB requirements. In this comparison, various technical solutions were selected so that the building complied with EC recommendations. Then the technical solutions were adjusted to achieve the closest compliance with the national NZEB requirements in the four selected EU countries. The technical solutions showing the highest energy performance highlighted the strictest national NZEB requirements. Energy performance with national NZEB solutions was benchmarked against the EC recommendation by using input data representing a standard use and applying the ISO 52000-1:2017 primary energy factors (PEF showed that the direct comparison of the building energy performance between the EC recommendation and the national nZEB primary energy values produced inconsistent results because of the variation of both the primary energy factors and the energy calculation input data in national regulations. This complicates free movement of goods and services and overall export between member states. More information is needed on what kind of building properties are required in different countries to guarantee fulfilment of nZEB requirements.

Fisk (2017) showed, by literature review, that ventilation rates in classrooms often fall far short of the minimum ventilation rates specified in standards. It is important to assure healthy and clean environments to children in day-care centres because wheezing and other breathing related issues in preschool children are common (Grigg and Ducharme, 2019) and more than half of all school children have some kind of allergic condition (asthma, eczema and seasonal allergic rhinitis) (Haanpää et al., 2018). Kolarik et al. (2016) showed a statistically significant inverse relationship between sick-leave and the ventilation air exchange rate in day-care centres. Therefore, it is extremely important that energy savings do not bring about a deterioration of the indoor climate.

It is quite common that the real measured building energy consumption is much higher than the predicted consumption during design (de Wilde, 2014; Desideri et al., 2012). This performance gap hinders the realisation of energy conservation targets. Achieving nearly Zero-Energy Buildings (nZEB) needs multi-attribute assessment (Zavadskas et al., 2017), as in addition to nearly zero or a very low amount of energy required, this required energy should be provided to a very significant extent by energy from renewable sources, including energy from renewable sources produced on-site or nearby.

To guarantee nearly zero or a very low amount of energy use, the building envelope and service systems should be very effective. Heat loss of the building envelope depends on thermal transmittance $U, W /\left(m^{2} \cdot K\right)$, linear thermal transmittance $\Psi, W /(m \cdot K)$, point thermal transmittance $\chi, W / K$, and airtightness of the building envelope $q_{50}, \mathrm{~m}^{3} /\left(\mathrm{hm}^{2}\right)$. Bikas and Chastas (2014) showed that in all climatic zones, the reduction of the thermal transmittance leads to a significant reduction in the primary energy consumption by end use, and in the energy requirements for heating. For example, the thermal transmittance of the external walls for nZEB should be $5 \%$ of older buildings thermal 
transmittance in Latvia, 10\% in Estonia and up to 50\% in Portugal (Kalamees et al., 2016). Ilomets et al., (2017) showed that that thermal bridges contribute more than $30 \%$ of the total transmission heat loss, depending on the wall insulation thickness. Levinskyte et al., (2016) showed that when effective solutions for linear thermal bridges are used, the same energy efficiency of the building can be reached using less thermal insulating layers and windows and doors of a lower thermal behaviour, if a building with better energy characteristics is designed. The existing situation of airtightness of the building envelope is often not sufficient (Banionis et al., 2013). Better information about effective energy performance measures helps design and construct buildings with a smaller performance gap. In addition to operational energy use, embodied energy (Kylili et al., 2016) is also important, as the latest EPBD targets decarbonised building stock by 2050 (EPBD, 2018). Greater use of woodbased materials helps to reduce fossil energy use and to mitigate climate change. The primary energy used and the $\mathrm{CO}_{2}$ emission resulting from production are lower for wood-framed constructions than for concrete-framed constructions (Gustavsson and Joelsson, 2010).

This paper is focused on data collected from existing nZEB day-care centres, in order to be able to assess possible differences between predicted and actual energy and indoor environmental performance. The main objectives of current study are:

_ To determine the technical solutions of modern, energy efficient, and nZEB day-care centres;

- To find out possible differences between predicted and actual energy and indoor environmental performance;

- To map the shortcomings that should be considered when designing future nZEB day-care centres.

Lessons learnt from previously constructed nZEB buildings can be utilised in the planning and design of new nZEBs.

\section{Studied buildings}

The energy use, indoor climate, and building envelope structures were investigated in five daycare centres in three countries, Table 1, Table 2, and Fig. 1. Most of the day-care centres were wooden buildings.

\begin{tabular}{|c|c|c|c|c|c|}
\hline Building description & Estonia 1 & Estonia 2 & Finland 1 & Finland 2 & Norway 1 \\
\hline Construction year & 2017 & 2017 & 2015 & 2014 & 2013 \\
\hline Net floor area, $\mathrm{m}^{2}$ & 1539 & 1172 & 1170 & 1192 & 950 \\
\hline Mean occupant density, & $10 \mathrm{~m}^{2} /$ person & $12 \mathrm{~m}^{2} /$ person & $10 \mathrm{~m}^{2} /$ person & $10 \mathrm{~m}^{2} /$ person & $14.4 \mathrm{~m}^{2} /$ person \\
\hline Ventilation system & \multicolumn{5}{|c|}{ Supply-exhaust air handling units with heat recovery } \\
\hline $\begin{array}{l}\text { Heating system / } \\
\text { heat source }\end{array}$ & $\begin{array}{l}\text { Floor and ra- } \\
\text { diator heating } \\
\text { /Gas boiler }\end{array}$ & $\begin{array}{c}\text { Floor and ra- } \\
\text { diator heating } \\
\text { / GSHP }\end{array}$ & \begin{tabular}{|l|} 
Floor and \\
radiator heat- \\
ing/Gas boiler
\end{tabular} & $\begin{array}{c}\text { Floor heating / } \\
\text { Ground source } \\
\text { heat pump (GSHP) }\end{array}$ & $\begin{array}{l}\text { Radiator heat- } \\
\text { ing / GSHP }\end{array}$ \\
\hline Cooling system / source & None & $\begin{array}{c}\text { Cooling coil in } \\
\text { ventilation / } \\
\text { GSHP }\end{array}$ & $\begin{array}{l}\text { Cooling coil in } \\
\text { ventilation / } \\
\text { Air heat pump }\end{array}$ & None & $\begin{array}{c}\text { Cooling coil in } \\
\text { ventilation / } \\
\text { GSHP } \\
\end{array}$ \\
\hline $\begin{array}{l}\text { On site renewable energy } \\
\text { systems }\end{array}$ & None & $\begin{array}{c}\text { PV-panels } \\
17 \mathrm{~kW}\end{array}$ & None & Geothermal heat & $\begin{array}{l}\text { Solar collec- } \\
\text { tors } 6 \mathrm{~m}^{2}\end{array}$ \\
\hline $\begin{array}{l}\text { Designed Energy Perfor- } \\
\text { mance Certificate (EPC) }\end{array}$ & $\begin{array}{c}\text { C } \\
\text { (minimum } \\
\text { requirements) }\end{array}$ & $\begin{array}{c}\mathrm{A} \\
(\mathrm{nZEB})\end{array}$ & $\begin{array}{c}\text { C } \\
\text { (minimum } \\
\text { requirements) }\end{array}$ & $\begin{array}{c}\text { B } \\
\text { (low energy } \\
\text { building) }\end{array}$ & $\begin{array}{c}\text { NS } 3700 \\
\text { (Norwegian } \\
\text { PH) }\end{array}$ \\
\hline Heating degree days, $t_{b} 17^{\circ} \mathrm{C}$ & 4220 & 4220 & 4392 & 4392 & 4302 \\
\hline Vent. airflow rate & $1.6 \mathrm{l} /\left(\mathrm{m}^{2} \mathrm{~s}\right)$ & & $2.5 \mathrm{l} /\left(\mathrm{m}^{2} \mathrm{~s}\right)$ & & $2.4 \mathrm{l} /\left(\mathrm{m}^{2} \mathrm{~s}\right)$ \\
\hline Heat recovery efficiency & $75 \%$ & & $67 \%$ & $76 \%$ & $85 \%$ \\
\hline Specific fan power & $2.0 \mathrm{~kW} /\left(\mathrm{m}^{3} / \mathrm{s}\right)$ & $\approx 2.0 \mathrm{~kW} /\left(\mathrm{m}^{3} / \mathrm{s}\right)$ & $1.85 \mathrm{~kW} /\left(\mathrm{m}^{3} / \mathrm{s}\right)$ & $1.9 \mathrm{~kW} /\left(\mathrm{m}^{3} / \mathrm{s}\right)$ & $1.3 \mathrm{~kW} /\left(\mathrm{m}^{3} / \mathrm{s}\right)$ \\
\hline
\end{tabular}

\section{Table 1}

Basic information of studied day-care centres 
Table 2

Characteristics of building envelope

Fig. 1

Studied day-care centres

\begin{tabular}{|c|c|c|c|c|c|}
\hline & Estonia 1 & Estonia 2 & Finland 1 & Finland 2 & Norway 1 \\
\hline \multicolumn{6}{|c|}{ Thermal transmittance $\mathrm{U}, \mathrm{W} /\left(\mathrm{m}^{2} \mathrm{~K}\right)$} \\
\hline Exterior walls & 0.19 & 0.13 & 0.17 & 0.15 & 0.09 \\
\hline Roof & 0.10 & 0.06 & 0.09 & 0.08 & 0.09 \\
\hline Ground floor & 0.20 & 0.09 & 0.16 & 0.16 & 0.08 \\
\hline Doors & 1.00 & 1.10 & 1.00 & 1.00 & 0.80 \\
\hline Windows & 1.00 & 0.85 & 1.00 & 0.84 & 0.80 \\
\hline Window g-value & $0.25-0.50$ & $<0.50$ & 0.36 & 0.36 & 0.37 \\
\hline Airtightness $\mathrm{q}_{50}, \mathrm{~m}^{3} /\left(\mathrm{h} \cdot \mathrm{m}^{2}\right)$ & $3.8^{*}$ & 0.6 & 2.0 & 0.36 & 0.14 \\
\hline Building structures & $\begin{array}{l}\text { Timber } \\
\text { frame }\end{array}$ & $\begin{array}{l}\text { Concrete } \\
\text { elements }\end{array}$ & $\begin{array}{l}\text { Timber } \\
\text { frame }\end{array}$ & $\begin{array}{l}\text { Timber } \\
\text { frame }\end{array}$ & $\begin{array}{c}\text { Cross laminated } \\
\text { timber }\end{array}$ \\
\hline
\end{tabular}

* Measured value

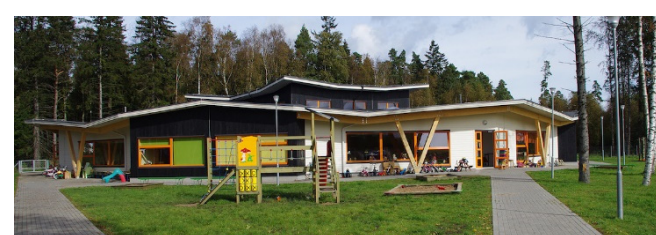

Estonia 1

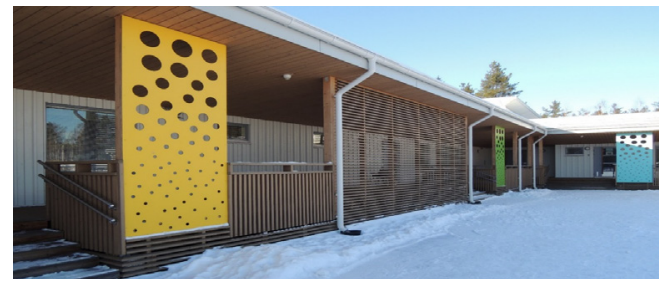

Finland 1

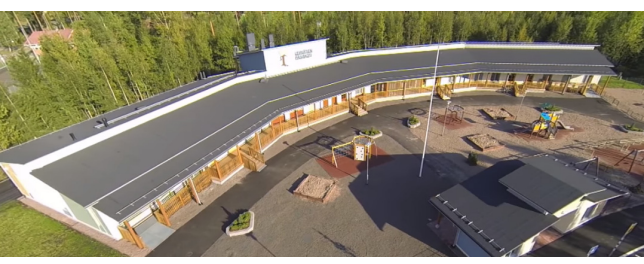

Finland 2

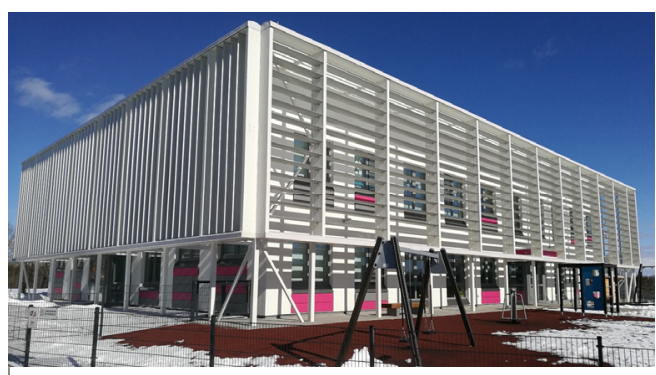

Estonia 2

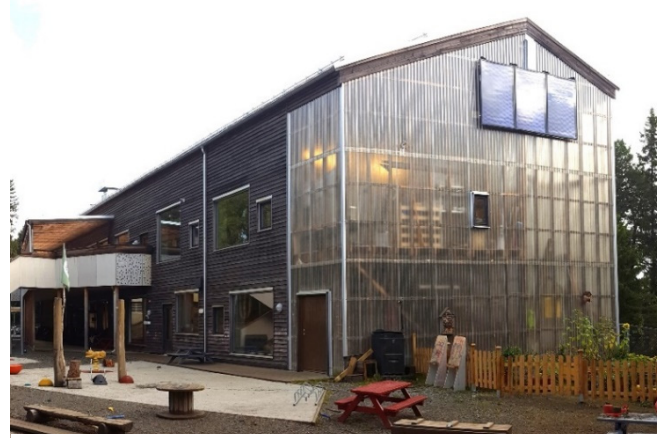

Norway 1

\section{Evaluating energy consumption and indoor climate}

Energy audits were done for each building to show the energy consumption. The information regarding energy consumption (electricity, space heating together with ventilation air heating (heat) and domestic hot water (DHW)) was measured and data was collected from building managers. Heating energy consumption is normalised to the standard year climate conditions.

To compare the gap between designed and measured energy consumption levels, we have used the following equation (Equation 1):

$$
\text { Performance gap }=\frac{100 \times(\text { Measured }(M)-\text { Designed }(D))}{\text { Measured }(M)} \%
$$

Indoor climate conditions were evaluated according to the standard EN-15251 (2007). Indoor environment quality is divided into four categories: I, II, III and IV, Table 3. Category I represents the 


\begin{tabular}{l|c|c|c|c}
\hline Indoor climate parameter & $\square$ IV & $\square$ III & $\square$ II & $\square$ I \\
\hline$t_{\text {heating, }}{ }^{\circ} \mathrm{C}$ & $\mathrm{T}<19$ or $\mathrm{T}>25$ & $22 \pm 3$ & $22 \pm 2$ & $22 \pm 1$ \\
\hline$t_{\text {cooling }},{ }^{\circ} \mathrm{C}$ & $\mathrm{T}<22$ or $\mathrm{T}>27$ & $24.5 \pm 2.5$ & $24.5 \pm 1.5$ & $24.5 \pm 1$ \\
\hline $\mathrm{CO}_{2}, \mathrm{ppm}$ & $>1200$ & $<1200$ & $<900$ & $<750$ \\
\hline
\end{tabular}

Table 3

Indoor temperature range in different climate categories

highest level of expectation and is recommended for spaces occupied by sensitive persons such as the elderly and children. Category II represents normal conditions and should be used as the target for new and renovated buildings. Category III is the minimum an existing building should reach, while Category IV represents IEQ that should be acceptable for only a limited part of the year.

Indoor climate conditions measurements (air temperature, $\mathrm{RH}$, air velocity, $\mathrm{CO}_{2}$ ) were conducted across the occupancy period from Monday to Friday during both heating (winter), and cooling (summer) seasons of occupancy. Measurements were conducted in all buildings in at least 2-4 rooms during the heating and cooling periods. The temperature and humidity were measured with portable data loggers. Airflow was measured using the supply and exhaust air airflows.

Indoor climate conditions were also assessed with occupant surveys delivered to employees. The survey included six questions regarding indoor environment quality including; thermal comfort, indoor air quality, acoustics, odour, and illuminance. Thermal comfort, IAQ, illuminance, and acoustics were assessed with a four-point scale from clearly acceptable to clearly unacceptable. Odour was scaled with six possible answers from no odour to overpowering odour. Thermal sensation was also surveyed with six possible answers from hot to cold.

\section{Measurements}

\section{Thermal comfort}

During the heating season, the room temperature corresponded to indoor climate category I or II criteria $87 \%$ - 100\% of the time, Fig. 2, Fig. 3. During the cooling season correspondence to indoor climate category I or II criteria was much smaller: 21\% - 54\% of time in Estonia, 15\% - 37\% in Finland, and in Norway $100 \%$ of the time. Thermal environment during the cooling season is in
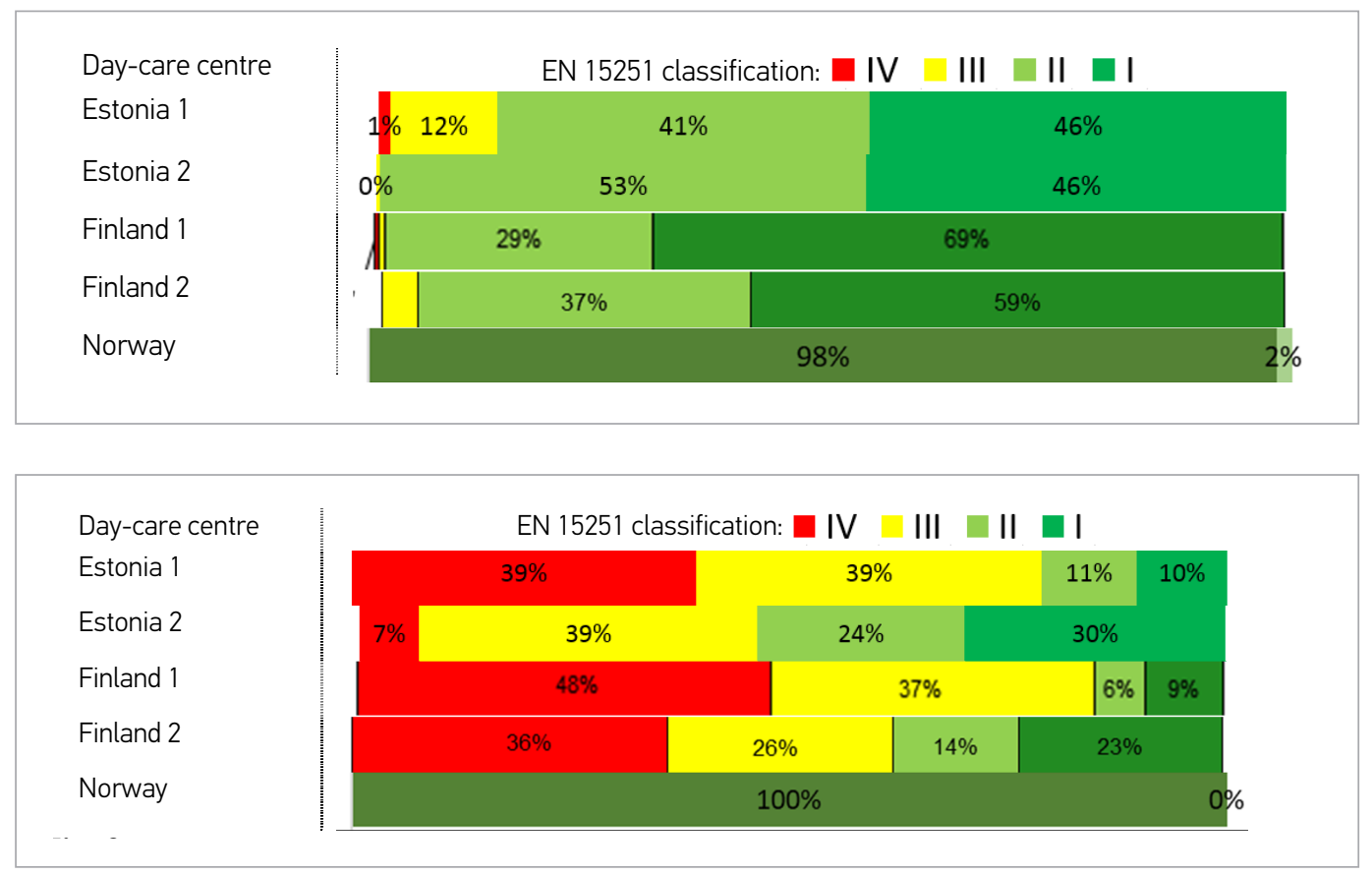

Fig. 3

Thermal comfort results in studied day-care centres during cooling season 
indoor climate categories III and IV because the measured room temperature was lower than the minimum temperature for indoor climate category II.

\section{Indoor air quality}

Indoor air quality was evaluated based on indoor $\mathrm{CO}_{2}$ concentration measurements during heating (Fig. 4) and cooling (Fig. 5) seasons. During the heating season, the indoor air quality corresponded to indoor climate category I or II criteria 65 - 99\% of time and during the cooling season $64-100 \%$ of time.

Average $\mathrm{CO}_{2}$ levels were in the acceptable level, Table 4.

Fig. 4

Indoor air quality results during heating season

Fig. 5

Indoor air quality results during cooling season

Table 4

Average $\mathrm{CO}_{2}$ levels and ventilation air flow during occupancy period in studied day-care centres

Table 5

Summary of occupant satisfaction with the indoor climate

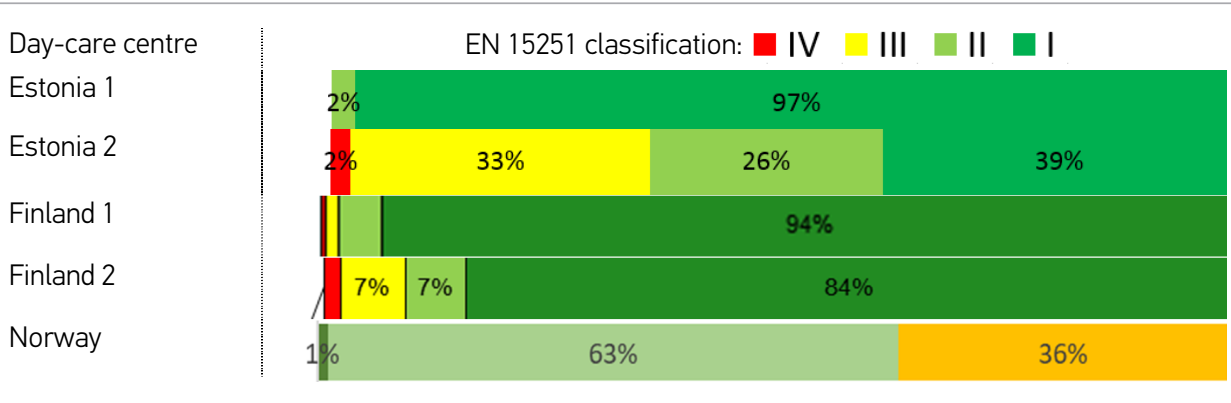

Day-care centre

Estonia 1

Estonia 2

Finland 1

Finland 2

Norway

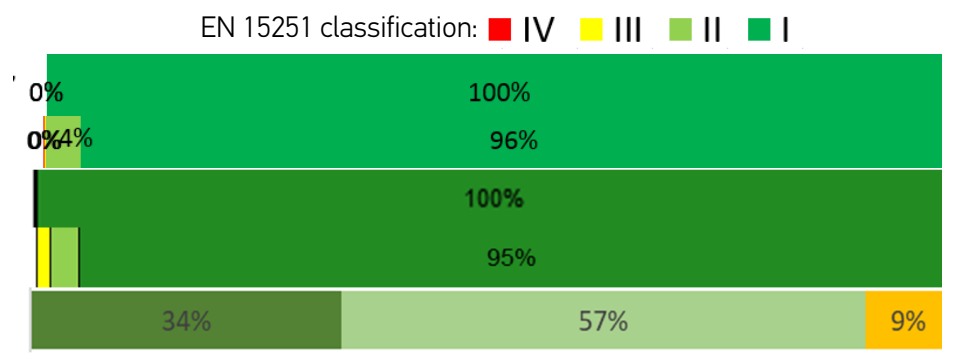

\begin{tabular}{c|c|c|c|c|c|}
\hline \multirow{2}{*}{$\mathrm{CO}_{2}$ level during occupancy, ppm } & \multicolumn{5}{|c}{ Occupant (satisfaction), \% } \\
\cline { 2 - 6 } & Estonia 1 & Estonia 1 & Finland 1 & Finland 2 & Norway \\
\hline Heating season & 547 & 808 & 501 & 553 & 497 \\
\hline Cooling season & 516 & 496 & 410 & 424 & 359 \\
\hline
\end{tabular}

\section{Occupant surveys}

The overall indoor environment was very good as occupant satisfaction was $90 \%$ or more, Table 5.

\begin{tabular}{l|c|c|c|c|c|}
\hline \multirow{2}{*}{} & \multicolumn{5}{|c}{ Occupant (satisfaction), \% } \\
\cline { 2 - 6 } & Estonia 1 & Estonia 2 & Finland 1 & Finland 2 & Norway \\
\hline Overall indoor environment & 100 & 100 & 94 & 93 & 90 \\
\hline Thermal environment & 100 & 100 & 100 & 82 & 90 \\
\hline Indoor air quality & 100 & 100 & 88 & 100 & 80 \\
\hline Illuminance level & 100 & 100 & 100 & 100 & 100 \\
\hline Acoustic level & 100 & 100 & 100 & 88 & 91 \\
\hline Odour intensity & 100 & 100 & 81 & 94 & 90 \\
\hline
\end{tabular}


Table 6 presents annual delivered and primary energy use in the studied day-care centers. Energy use in the Norwegian day-care center was lower than designed. In other day-care centers this was contrariwise. The energy performance certificate was two to four classes lower in the studied buildings, Fig. 6 left. The performance gap varied between $25 \%-67 \%$ and it was larger in more energy efficient buildings, Fig. 6 right.

\begin{tabular}{l|c|c|c|c|c|c}
\hline & \multicolumn{5}{c}{ Energy use, $\mathrm{kWh} /\left(\mathrm{m}^{2} \mathrm{a}\right)$} \\
\cline { 2 - 6 } & Estonia 1 & Estonia 2 & Finland 1 & Finland 2 & Norway \\
\hline Delivered energy & 146 & 45 & 133 & 71 & 71 \\
\hline Designed & 202 & 125 & 327 & 121 & 46 \\
\hline Measured & $28 \%$ & $64 \%$ & $59 \%$ & $41 \%$ & $-54 \%$ \\
\hline Performance gap & 189 & 83 & 169 & 152 & - \\
\hline Energy Performance Value (Primary energy) & & & & & \\
\hline Designed & 251 & 249 & 401 & 258 & - \\
\hline Measured & $25 \%$ & $67 \%$ & $58 \%$ & $41 \%$ & - \\
\hline Performance gap & & & & & \\
\hline
\end{tabular}

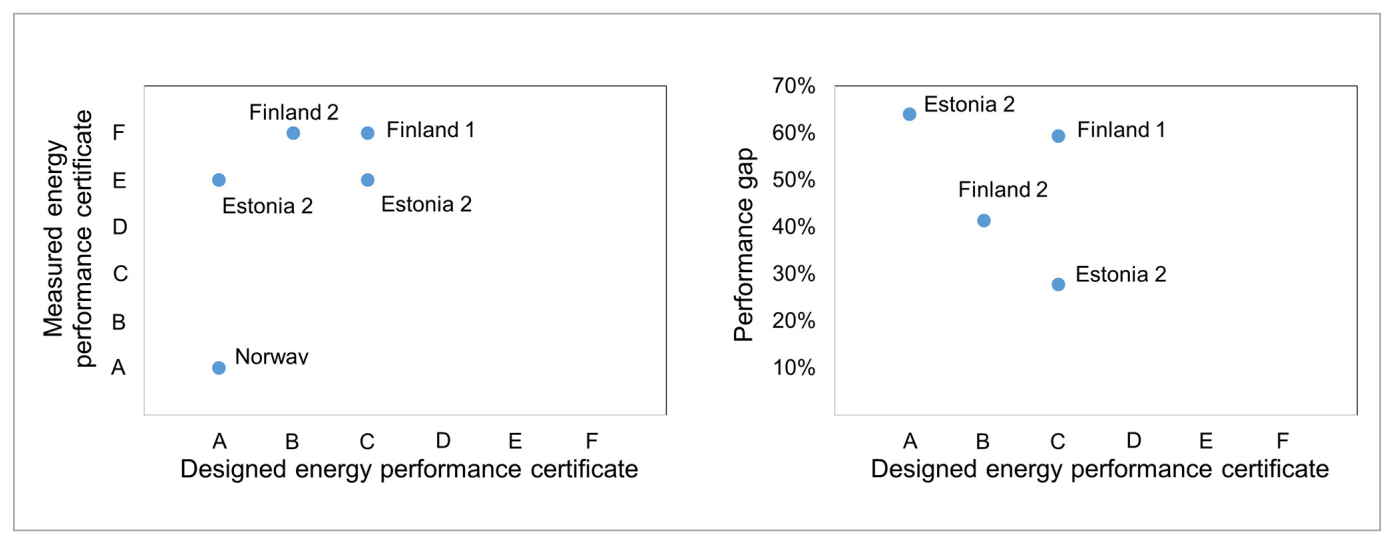

Measured real energy use was higher, or even significantly higher, than the energy use calculated during the design phase. Raide et al. (2015) monitored and simulated performance of energy use, indoor climate, and building service systems of the day-care center that was designed according to passive house standards. Buildings did not meet the desired levels because of a lack of robust project leadership and final component selection. Because of a too simplified control of building service systems and over optimistic and inadequate assumptions in energy calculations and initial data, energy performance targets were not realised. The energy performance gap was larger for more energy efficient buildings. When energy use is small, then small changes may cause a large relative difference. Arumägi and Kalamees (2016) showed that in designing of very energy efficient buildings, more thorough analyses are needed in the very first stage of the design, to find suitable solutions and possible compromises. If, in today's design practice, during the preliminary design phase, only minor analysis is done, then design practice should change when moving towards nZEB.

Norwegian day-care center that was designed, constructed and commissioned according to passive house standards fulfilled EPC promises. Even more - measured real energy use was smaller

\section{Energy Performance}

\section{Table 6}

Annual energy use in studied day-care centres

\section{Fig. 6}

Comparison between designed and real measured energy performance certificate (left) and dependence of performance gap on designed energy performance certificate in buildings where energy performance targets were not fulfilled

\section{Discussion}


than designed. A more accurate and robust commissioning, design and construction process is needed for future nZEB day-care centers.

The exact reason of higher energy use was difficult to determine. The total energy use was measured, but there lack detailed and separated energy measuring of energy use in smaller subdivision. For future nZEB day care centers we recommend measuring separately:

heat consumption for room heating, heating of ventilation air, heating of DHW,

- electricity consumption for fans-pumps, appliance-lightning, cooling

on-site energy production: heat, electricity.

Potential reasons for the higher measured energy use are caused by the methodology of the energy calculations and the differences in user behavior. Some of the appliances, which may have a significant share of the buildings overall energy consumption, like hot kitchens, missing of heat recovery unit in kitchens, swimming pools, and outdoor lighting, are not taken into account in the energy calculations. Indoor temperature during the heating season tended to be higher than the $+21^{\circ} \mathrm{C}$ used in the energy calculations. Measurements showed that occupants preferred an indoor temperature around $+22 \ldots+23^{\circ} \mathrm{C}$. Also usage activity and occupant density influence energy use. Sekki et al. (2015) studied day-care centers in Finland and showed that the more $\mathrm{m}^{2} / \mathrm{child}$, the more energy the building consumes (even then, there were great variations between the buildings (Sekki et al., 2015b)). Therefore, we recommend making energy simulations based as much as possible on the future building's usage profile, as well as standard simulations.

The designed delivered energy use in Finnish day care center 2 was $71 \mathrm{kWh} /\left(\mathrm{m}^{2} \cdot \mathrm{K}\right)$. Sankelo et al. (2018) showed that with the similar initial investment cost it would be possible to reach to much lower energy use and cost optimal levels for day-care centres lie on $35-40 \mathrm{kWh} /\left(\mathrm{m}^{2} \cdot \mathrm{K}\right)$ for buildings with GSHP and $70-80 \mathrm{kWh} /\left(\mathrm{m}^{2} \cdot \mathrm{K}\right)$ for buildings with district heating.

Thermal environment corresponded to the climate categories I and II better during heating season. During summer season the room temperature was too cool mainly because of low spring-summer period.

Even though measured ventilation air flow rates did not fulfill designed values, based on $\mathrm{CO}_{2}$ levels, indoor air quality targets were fulfilled most of the time. This indicates that window airing was used to compensate for missing ventilation airflow. Window airing does not provide any heat recovery or filtration possibilities. This could cause a deterioration of indoor air quality (depending on the location of the building) and energy performance.

Indoor climate condition measurements showed that, in general, the thermal environment and indoor air quality in 5 modern day-care centres in Estonia, Finland and Norways corresponded to the highest indoor climate categories I and II (EN 15251). Building heating and ventilation systems in the studied buildings are working without major problems. Good indoor climate conditions were also reflected in the occupant satisfaction questionnaires. For most of the studied buildings, over $80 \%$ of the people marked all indoor environment condition parameters (thermal comfort, indoor air quality, acoustics, odour and illuminance) as acceptable.

Energy consumption analysis showed that problems exist between the calculated and measured values. In most of the studied buildings, measured energy consumption is higher or even significantly higher than designed values. Potential causes of the higher actual energy consumption are caused by differences between measured and designed solutions, the methodology of the energy calculations and the differences in user behaviour. Some of the appliances, which may have a significant share of the buildings overall energy consumption, like hot kitchens, swimming pools and outdoor lighting are not taken into account in the energy calculations. Indoor temperature in the heating season tended to be higher than the $21^{\circ} \mathrm{C}$ used in the energy calculations. Measurements showed that occupants prefer an indoor temperature of around $22 \ldots 23^{\circ} \mathrm{C}$. 
This research utilises measurement data from H2020 project No 754177: "NERO - Cost reduction of new Nearly Zero-Energy Wooden buildings in the Northern Climatic Conditions". The research was co-financed by the Estonian Research Council with Personal research funding PRG483 "Moisture safety of interior insulation, constructional moisture and thermally efficient building envelope", Institutional research funding grant IUT1-15, Estonian Centre of Excellence in Zero Energy and Resource Efficient Smart Buildings and Districts, ZEBE, grant TK146 funded by the European Regional Development Fund.

Arumägi, E., Kalamees, T., 2016. Design of the first net-zero energy buildings in Estonia. Science and Technology for the Built Environment 22. https:// doi.org/10.1080/23744731.2016.1206793

Banionis, K., Šadauskienè, J., Paukštys, V., Šeduikytè, L., Ramanauskas, J., 2013. Diagnostics and Problems Analysis of Buildings Air Tightness. Journal of Sustainable Architecture and Civil Engineering 3, 52-58. https://doi.org/10.5755/j01.sace.3.4.4375

Bikas, D., Chastas, P., 2014. The Effect of the U Value in the Energy Performance of Residential Buildings in Greece. Journal of Sustainable Architecture and Civil Engineering 6, 58-65. https://doi.org/10.5755/j01.sace.6.1.5950

de Wilde, P., 2014. The gap between predicted and measured energy performance of buildings: A framework for investigation. Automation in Construction 41, 40-49. https://doi.org/10.1016/j.autcon.2014.02.009

Desideri, U., Yan, J., Menezes, A.C., Cripps, A., Bouchlaghem, D., Buswell, R., 2012. Predicted vs. actual energy performance of non-domestic buildings: Using post-occupancy evaluation data to reduce the performance gap. Applied Energy 97, 355-364. https://doi.org/10.1016/j.apenergy.2011.11.075

EN-15251, 2007. Indoor environmental input parameters for design and assessment of energy performance of buildingsaddressing indoor air quality, thermal environment, lighting and acoustics.

EPBD, 2018. Directive (EU) 2018/844 of the European Parliament and of the Council of 30 May 2018 amending Directive 2010/31/EU on the energy performance of buildings and Directive 2012/27/EU on energy efficiency. Official Journal of the European Union 30 May. EPBD, 2010. DIRECTIVE 2010/31/EU OF THE EUROPEAN PARLIAMENT AND OF THE COUNCIL of 19 May 2010 on the energy performance of buildings (recast). Official Journal of the European Union L153, 13-35.

Fisk, W.J., 2017. The ventilation problem in schools: literature review. Indoor Air 27, 1039-1051. https:// doi.org/10.1111/ina.12403

Grigg, J., Ducharme, F.M., 2019. Asthma in the Preschool Age Child. Kendig's Disorders of the Respiratory Tract in Children 677-685.e2. https://doi. org/10.1016/B978-0-323-44887-1.00044-4
Gustavsson, L., Joelsson, A., 2010. Life cycle primary energy analysis of residential buildings. Energy and Buildings 42, 210-220. https://doi. org/10.1016/j.enbuild.2009.08.017

Haanpää, L., af Ursin, P., Nermes, M., Kaljonen, A., Isolauri, E., 2018. Association of allergic diseases with children's life satisfaction: population-based study in Finland. BMJ Open 8, e019281. https://doi. org/10.1136/bmjopen-2017-019281

Ilomets, S., Kuusk, K., Paap, L., Arumägi, E., Kalamees, T., 2017. Impact of linear thermal bridges on thermal transmittance of renovated apartment buildings. Journal of Civil Engineering and Management 23, 96-104. org/10.3846/13923730.2014.976259

Kalamees, T., Lupišek, A., Mørck, O.C., Borodinecs, A., Aalmeida, M., Rovers, R., Veld, P.O. 't, Kuusk, K., Silva, S., 2016. What kind of heat loss requirements nZEB and deep renovation sets for building envelope?, in: Central Europe Towards Sustainable Building 2016: Innovations for Sustainable Future, CESB 2016. University Centre for Energy Efficient Buildings Czech Technical University in Prague, 2224 June 2016 Prague, Czech Republic, pp. 137-144.

Kolarik, B., Andersen, Z.J., Ibfelt, T., Engelund, E.H., Møller, E., Bräuner, E.V., 2016. Ventilation in day care centers and sick leave among nursery children. Indoor Air 26, 157-167. https://doi.org/10.1111/ina.12202

Kurnitski, J., Ahmed, K., Hasu, T., Kalamees, T., Lolli, N., Lien, A., Johan, T., Jan, J., 2018. NZEB energy performance requirements of four North ... against official recommendations of European Commission, in: Proceedings of the REHVA Annual Meeting Conference Low Carbon Technologies in HVAC. 23 April 2018, Brussels, Belgium, p. 8.

Kylili, A., Fokaides, P.A., Seduikyte, L., 2016. Sustainability tools for the assessment of construction materials and buildings. Journal of Sustainable Architecture and Civil Engineering 16, 61-69. https:// doi.org/10.5755/j01.sace.16.3.16172

Levinskyte, A., Banionis, K., Geleziunas, V., 2016. The Influence of Thermal Bridges for Buildings Energy Consumption of "A" Energy Efficiency Class. Journal of Sustainable Architecture and Civil Engineering 15, 47-58. https://doi.org/10.5755/j01.sace.15.2.15351

\section{Acknow- ledgment}

\section{References}


Raide, I., Kalamees, T., Mauring, T., 2015. Lessons learnt from the first public buildings in Estonia intended to be passive houses. Proceedings of the Estonian Academy of Sciences 64, 157. https://doi. org/10.3176/proc.2015.2.04

Sankelo, P., Jokisalo, J., Nyman, J., Vinha, J., Sirén, K., 2018. Cost-optimal energy performance measures in a new daycare building in cold climate. International Journal of Sustainable Energy 1-19. https://doi.org/10.1080/14786451.2018.1448398

Sekki, T., Airaksinen, M., Saari, A., 2015a. Impact of building usage and occupancy on energy con- sumption in Finnish daycare and school buildings. Energy and Buildings 105, 247-257. https://doi. org/10.1016/j.enbuild.2015.07.036

Sekki, T., Airaksinen, M., Saari, A., 2015b. Measured energy consumption of educational buildings in a Finnish city. Energy and Buildings 87, 105-115. https://doi.org/10.1016/j.enbuild.2014.11.032

Zavadskas, E.K., Antucheviciene, J., Kalibatas, D., Kalibatiene, D., 2017. Achieving Nearly Zero-Energy Buildings by applying multi-attribute assessment. Energy and Buildings 143, 162-172. https://doi. org/10.1016/j.enbuild.2017.03.037

\section{About the KALLE KUUSK Authors Senior Research Scientist}

Tallinn University of Technology, Estonia

Main research area

Energy performance of buildings

\section{Address}

Ehitajate tee 5, Tallinn E-mail:

kalle.kuusk@taltech.ee

AHMED KAISER
Doctoral Candidate
Aalto University,
Finland
Main research area
Energy performance of
buildings

Address

Otakaari 1 B, Espoo

E-mail:

kaiser.ahmed@aalto.fi

\section{NICOLA LOLLI \\ Research Scientist \\ SINTEF, Norway \\ Main research area \\ Energy performance of buildings}

\section{Address}

Strindveien 4,

Trondheim

E-mail:nicola.lolli@ sintef.no

\section{JAN JOHANSSON \\ Energy Manager \\ Växjö Kommun, \\ Sweden}

\section{Main research area}

Energy performance of buildings

\section{Address}

Västra Esplanaden 18,

Växjö

E-mail: jan.

johansson3@vaxjo.se

\section{TERO HASU}

Specialist

Kouvola Innovation Ltd., Finland

\section{Main research area}

Energy performance of buildings

\section{Address}

Paraatikenttä 4, Kouvola

E-mail: tero.hasu@kinno.fi

\section{ANNE GUNNARSHAUG LIEN}

Senior Research Scientist

SINTEF, Norway

Main research area

Energy performance of buildings

Address
Strindveien 4,
Trondheim
E-mail: anne.g.lien@
sintef.no

\section{ENDRIK ARUMÄGI}

Senior Research Scientist

Tallinn University of Technology, Estonia

Main research area

Energy performance of buildings

\section{Address}

Ehitajate tee 5, Tallinn

E-mail: endrik.

arumagi@taltech.ee

\section{KRISTO KALBE \\ Expert}

Tallinn University of Technology, Estonia

\section{Main research area}

Energy performance of buildings

\section{Address}

Ehitajate tee 5, Tallinn E-mail:kristo.kalbe@ taltech.ee

\section{JAANUS HALLIK \\ Doctoral Candidate \\ Tallinn University of Technology, Estonia}

Main research area

Energy performance of buildings

\section{Address}

Ehitajate tee 5, Tallinn E-mail: jaanus.hallik@ taltech.ee

\section{JAREK KURNITSKI \\ Adjunct \\ Professor \\ Aalto University, \\ Finland \\ Main research area \\ Energy performance of buildings \\ Address \\ Otakaari 1 B, Espoo \\ E-mail: \\ jarek.kurnitski@aalto.i}

\section{TARGO KALAMEES}

\section{Professor}

Tallinn University of Technology, Estonia

\section{Main research area \\ Energy performance of} buildings

\section{Address}

Ehitajate tee 5, Tallinn E-mail: targo. kalamees@taltech.ee 